\title{
Effective Instruction for English Learners
}

\section{Margarita Calderón, Robert Slavin, and Marta Sánchez}

\section{Summary}

The fastest-growing student population in U.S. schools today is children of immigrants, half of whom do not speak English fluently and are thus labeled English learners. Although the federal government requires school districts to provide services to English learners, it offers states no policies to follow in identifying, assessing, placing, or instructing them. Margarita Calderón, Robert Slavin, and Marta Sánchez identify the elements of effective instruction and review a variety of successful program models.

During 2007-08, more than 5.3 million English learners made up 10.6 percent of the nation's K-12 public school enrollment. Wide and persistent achievement disparities between these English learners and English-proficient students show clearly, say the authors, that schools must address the language, literacy, and academic needs of English learners more effectively.

Researchers have fiercely debated the merits of bilingual and English-only reading instruction. In elementary schools, English learners commonly receive thirty minutes of English as a Second Language (ESL) instruction but attend general education classes for the rest of the day, usually with teachers who are unprepared to teach them. Though English learners have strikingly diverse levels of skills, in high school they are typically lumped together, with one teacher to address their widely varying needs. These in-school factors contribute to the achievement disparities.

Based on the studies presented here, Calderón, Slavin, and Sánchez assert that the quality of instruction is what matters most in educating English learners. They highlight comprehensive reform models, as well as individual components of these models: school structures and leadership; language and literacy instruction; integration of language, literacy, and content instruction in secondary schools; cooperative learning; professional development; parent and family support teams; tutoring; and monitoring implementation and outcomes.

As larger numbers of English learners reach America's schools, K-12 general education teachers are discovering the need to learn how to teach these students. Schools must improve the skills of all educators through comprehensive professional development—an ambitious but necessary undertaking that requires appropriate funding.

www.futureofchildren.org

Margarita Calderón is professor emerita of education at Johns Hopkins University. Robert Slavin is director of the Center for Research and Reform in Education at Johns Hopkins University. Marta Sánchez is a doctoral candidate in education at the University of North Carolina-Chapel Hill. 


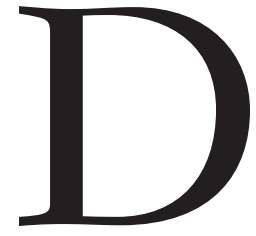

uring the 1960s, public schools in the United States served a student population that was about 80 percent white. Today, non-Hispanic whites make up 57 percent of the student population ${ }^{1}$ and are a minority in most large urban districts. The fastestgrowing student population in U.S. schools is children of immigrants, half of whom do not speak English well enough to be considered fluent English speakers. In 1974, the U.S. Supreme Court, in Lau v. Nichols, 414 U.S. 563 (1974), held that school districts must take affirmative steps to help students overcome language barriers so that they can participate meaningfully in each school district's programs. The U.S. government requires every school district that has more than 5 percent national-origin minority children with no or limited English proficiency to "take affirmative steps to rectify the language deficiency in order to open its instructional program to these students." ${ }^{2}$ To that end, school districts across the country determine whether children are Limited English Proficient (LEP), ${ }^{3}$ a federal designation for children whose English proficiency is too limited to allow them to benefit fully from instruction in English. ${ }^{4}$ Such students are also called English language learners and English learners. ${ }^{5}$ But although the federal government requires districts to provide services to English learners, it offers states no policies to follow in identifying, assessing, placing, or instructing them. States, therefore, vary widely in the policies and practices by which they identify and assess English learners for placing within and exiting from instructional programs.

For the past sixty years, educators' discussions of English language learning have focused on whether instructors should use
English or students' native languages to enable nonnative English speakers to become proficient in English and in core content. We focus instead on identifying the elements of effective instruction, regardless of the language in which instruction is carried out. We set our discussion in the larger framework of whole-school reform as the basis of all students' academic success and examine eight characteristics of instruction for English learners that have generated successful outcomes for students in elementary, middle, and high schools.

\section{A Fast-Growing Population}

Mid-decade data reveal rapid growth in the U.S. English learner population. ${ }^{6}$ During the 2007-08 school year, English learners represented 10.6 percent of the K-12 public school enrollment, or more than 5.3 million students. ${ }^{7}$ In fact, English learners are the fastest-growing segment of the student population, with their growth highest in grades seven through twelve. ${ }^{8}$ Figures 1 and 2 show the dramatic increases in English learner populations, particularly in states that are not accustomed to serving their instructional needs. These students have lower academic performance and lower graduation rates than native white students and have affected the nation's overall educational attainment. ${ }^{9}$

About 79 percent of English learners in the United States speak Spanish as their native language; much lower shares speak Chinese, Vietnamese, Hmong, and Korean. About 80 percent of second-generation immigrant children, who by definition are native-born U.S. citizens, are what schools call longterm English learners. These students,who have been in U.S. schools since kindergarten, are still classified as limited English proficient when they reach middle or high school—suggesting strongly that preschool 
Figure 1. Number of English Language Learners (ELL) by State, 2007-08

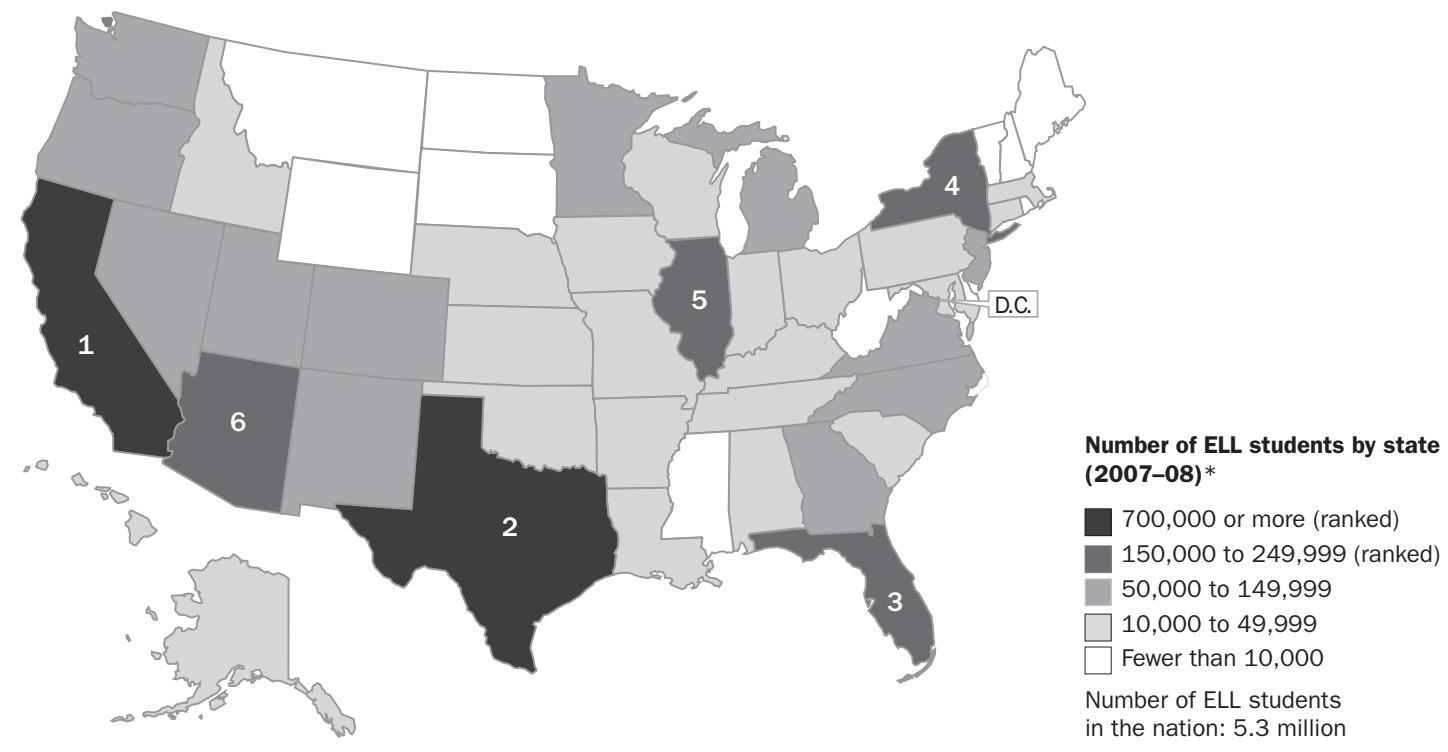

Source: National Clearinghouse for English Language Acquisition, State Title III Information System. ( 2010 Migration Policy Institute. Note: Numbers on the map show the top-ranked states by numbers of ELL students. There were no states with ELL populations between 250,000 and 700,000 .

*Includes ELLs from Puerto Rico and other outlying territories.

and elementary programs are not adequately addressing the needs of English learners. ${ }^{10}$

Alongside the long-term English learners, whose language and literacy gaps must be addressed if they are to graduate from high school, exist other categories of English learners with very different needs. One group is in special education. A second group was inappropriately reclassified as general education students after passing their district's language test. As the National Literacy Panel has found, assessments used to gauge language-minority students' language proficiency and to make placement and reclassification decisions are inadequate in most respects. ${ }^{11}$ And students who are not proficient in four essential domains-listening, speaking, reading, and writing-but are no longer classified as LEP continue to struggle with reading and academic coursework. Migrant
English learners, another group of English learners, are mainly U.S.-born but lack proficiency in English because their education is interrupted as their parents follow the crops from state to state. Transnational English learners return to their native countries for a year or a portion of the year and attend school in those countries. Some students classified as English learners move repeatedly within the same city, often returning to the same school during the school year, as their parents struggle to meet rent payments.

The remaining 20-30 percent of English learners are recent immigrants, but they too are a heterogeneous population. Some are highly schooled and know more geometry, geography, and science than mainstream twelfth graders and primarily need to learn the academic English language vocabulary, not core concepts. Other newcomers, called 
Figure 2. States with Large and Rapidly Growing Populations of English Language Learners (ELL)

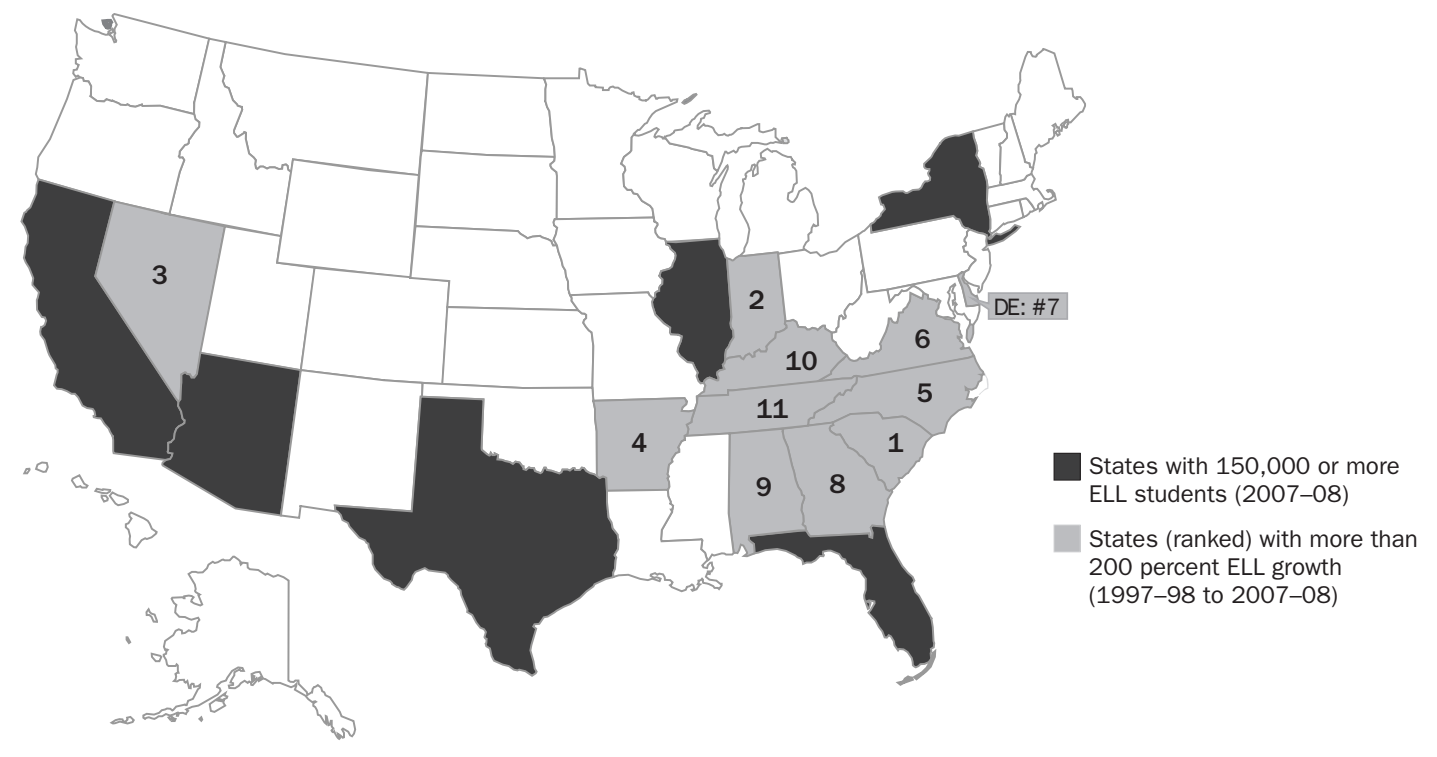

Note: Numbers on the map show the top-ranked states in ELL growth. There were no states with the size of ELL population between 250,000 and 700,000 .

Source: National Clearinghouse for English Language Acquisition, State Title III Information System. ๑ 2010 Migration Policy Institute.

students with interrupted formal education because their schooling was interrupted for two years or more before coming to the United States, have both literacy and subject matter gaps. Refugee children who have never attended school are yet another group of English learners whose academic needs go well beyond language learning, particularly if they enter U.S. schools in the upper grades. ${ }^{12}$

In spite of their striking diversity, English learners in secondary schools have typically been lumped into the same English as a Second Language (ESL) classroom, with one teacher addressing the needs of students with dramatically varied English proficiency, reading, and writing skills. In elementary schools, a common practice is to pull out English learners across grades K-5 for thirty minutes of ESL instruction. For the remainder of the day these English learners attend regular classes in a sink-or-swim instructional situation, usually with teachers who are unprepared to teach them. ${ }^{13}$

Researchers consistently find wide and persistent achievement disparities between English learners and English-proficient students-gaps that we believe signal a need for increased teacher and staff preparation, whole-school commitment to the English learner population, and home-school linkages and collaborations, ${ }^{14}$ so that schools can more effectively address these students' language, literacy, and core content needs. Such institutional preparedness is critical to addressing the achievement gaps seen across various age groups and academic content areas_-gaps that start early and persist even among second- and third-generation children of some immigrant groups. ${ }^{15}$ By disaggregating data and following English learner student achievement by cohorts, researchers can pinpoint more precisely the gaps in academic 
outcomes between English learners and other student groups ${ }^{16}$ Closing the achievement gaps means, in part, closing similar gaps in teacher preparation programs and ongoing professional development. Today most English learners spend their time in regular classrooms with teachers who feel that they are ill-prepared to meet their needs.

There is considerable controversy among policy makers, researchers, and educators about how best to ensure the language, reading, and academic success of English learners. Among the many aspects of instruction important to guarantee that success, for years one has dominated all others: What is the appropriate role of the native language in instructing English language learners? ${ }^{17}$ Since the 1960s, most U.S. schools with large populations of Spanish-speaking English learners have implemented various types of programs to instruct English learners in Spanish and in English. Some schools teach in Chinese and English or other native languages and English. Schools that serve students from many language backgrounds have implemented ESL programs, which teach only in English.

Recent federal policies have had the effect of restricting the time that can be spent teaching children in their native language. Federal accountability policies and diminishing funds make it impractical for local education agencies and schools to support native language instruction. Although federal policy has neither endorsed nor opposed instruction in the primary language, in recent years policy changes have discouraged bilingual education. Among researchers, the debate between advocates of bilingual and English-only reading instruction has been fierce, and ideology has often trumped evidence on both sides of the debate. ${ }^{18}$
Based on the findings from recent studies, as described in this article, what matters most in educating English learners is the quality of instruction. In our discussion of effective instruction, we highlight comprehensive reform models, as well as individual components of these models. Certain salient features or elements of quality instruction for English learners have been found to be effective from preschool to twelfth grades in either duallanguage programs or carefully structured English programs. We discuss the following eight elements: school structures and leadership; language and literacy instruction; integration of language, literacy, and content instruction in secondary schools; cooperative learning; professional development; parent and family support teams; tutoring; and monitoring implementation and outcomes.

\section{Methods}

In reviewing research on programs and practices to improve reading and language outcomes for English learners, we emphasize those that have been found to be effective. The research that we review meets several criteria. ${ }^{19}$ First, it primarily involves English learners. Second, it compares outcomes for students taught using a given program or practice (the treatment group) with outcomes for students taught using alternative approaches (the control group). Assignment to the treatment group can be randomized or matched, but treatment and control students must be within a half standard deviation of each other on pretests given before treatments began. Third, measures of outcomes are in English if the goal of the program is English language or reading, in other languages if these are the goal. Finally, we use mainly long-term studies where they are available and exclude evaluations that take place over a period of less than twelve weeks. Programs and practices emphasized are 
drawn primarily from reviews of research by Robert Slavin and Margarita Calderón, Alan Cheung and Robert Slavin, Diane August and Timothy Shanahan, Diane August and others, and from more recent research. ${ }^{20}$

\section{Comprehensive School Reform: Success for All}

One approach to improving outcomes for English learners and other language minority students is to reform the entire school, providing innovative approaches to curriculum, instruction, assessment, provisions for struggling students, professional development, and other elements. ${ }^{21}$ Numerous comprehensive school reform models for students in general were developed and evaluated during the 1980s and 1990s, and some have shown strong evidence of effectiveness overall. ${ }^{22}$ One of the most widely studied comprehensive school reform approaches, Success for All (SFA), has been adapted for English learners, and these adaptations too have been evaluated. ${ }^{23}$ In an analysis of school restructuring that meets the needs of all students, the National Research Council concluded that SFA has been the subject of the most research on effectiveness. ${ }^{24}$

Now used in about 1,000 schools in fortyseven states, SFA provides schools with well-structured curriculum materials emphasizing systematic phonics in grades $\mathrm{K}-1$, cooperative learning, and direct instruction in comprehension and vocabulary skills in all grades. It also provides extensive professional development and coaching for teachers, frequent assessment and regrouping, and one-to-one or small-group tutoring for children who are struggling to learn to read. Family support programs attend to issues such as parent involvement, attendance, and behavior. A full-time facilitator helps all teachers implement the model.
For English learners, SFA has two variations. One is a Spanish bilingual program, Éxito Para Todos, which teaches reading in Spanish in grades $\mathrm{K}-2$ and then transitions students to English instruction beginning in second or third grade. The other is a Structured English Immersion (SEI) adaptation, which teaches all children in English with appropriate supports, such as vocabulary-development strategies linked to the words introduced in children's reading texts. Since 2004, SFA has provided video content shown on DVDs or interactive whiteboards to model key vocabulary content for English learners. ${ }^{25}$

A National Institutes of Health longitudinal study found positive effects of SFA for English learners and other languageminority children ${ }^{26} \mathrm{~A}$ California study by Meg Livingston Asensio and John Flaherty ${ }^{27}$ found substantial positive effects both for English learners initially taught in Spanish and for those taught only in English, compared with control groups. A study in Houston of the bilingual adaptation of SFA found positive effects on English and Spanish reading measures. ${ }^{28}$ A Philadelphia study found positive effects of an SEI adaptation of SFA with Cambodian-speaking students. ${ }^{29}$

An Arizona study by Steven Ross, Lana Smith, and John Nunnery ${ }^{30}$ found that English learners who were taught with the SEI adaptation of SFA gained more than control students on English measures, and a Texas statewide evaluation found positive effects for Hispanic students in 111 SFA schools across the state, compared with other Texas schools serving Hispanic children. An evaluation of SFA with the video content just noted found strong positive effects on English reading. ${ }^{31}$ A national three-year longitudinal randomized evaluation of SFA found positive reading 
Schools that serve English

learners and other languageminority children, especially in regions where most families are struggling economically, provide children their best and perhaps only chance to achieve economic security.

effects for all students, but gains were greatest among a group of Hispanic students. ${ }^{32}$

The strong and consistent positive effects of SFA for English learners and other languageminority students show that comprehensive school reforms made up of many elements of effective practice can make substantial differences in children's outcomes. We discuss other studies that have provided evidence on the application of individual elements of SFA in following sections. A report by the Council on Advancing Adolescent Literacy, for example, offered a comprehensive agenda similar to SFA for re-engineering America's middle and high schools to support all learners. ${ }^{33}$

\section{Elements of Effective Practice for English Learners}

Along with strong evidence for the effectiveness of comprehensive school reforms for English learners, solid evidence of effectiveness also exists for many individual elements of the comprehensive approaches.

\section{School Structures and Leadership}

Schools that serve English learners and other language-minority children, especially in regions where most families are struggling economically, provide children their best and perhaps only chance to achieve economic security. Such schools cannot leave anything to chance. They must be organized to capitalize on all of their assets, including students' and parents' aspirations, staff professionalism and care, and other intangibles as well as financial and physical assets. Effective programs contain four structural elements.

The first element is constant collection and use of ongoing formative data on learning, teaching, attendance, behavior, and other important intermediate outcomes. School staffs must always be aware of which students are succeeding and failing and why. They must also have well-conceived plans to prevent or resolve problems and must monitor progress over time to learn whether attempted solutions are having their intended effects. ${ }^{34}$

The second element is a strong focus on professional development for all staff members, including administrators. Staff development must be intensive and ongoing, with many opportunities for both peer and expert coaching and information exchange among implementers of a given component as listed here, either in professional discussions in a school or with professionals from other schools.

The third element is standards of behavior and effective strategies for classroom and school management. It may involve specific programs, such as Consistency ManagementCooperative Discipline, ${ }^{35}$ or training in methods for organizing, motivating, and guiding students in class and in the school as a whole. ${ }^{36}$

The final element is leadership focused on building a "high-reliability organization" that shares information widely, monitors the 
quality of teaching and learning carefully, and holds all staff responsible for progress toward shared goals. ${ }^{37}$

\section{Language and Literacy Development}

A key indicator of verbal ability (which has long been the basis of grade-level tests, college entrance exams, and selection tests for graduate school) is vocabulary knowledge. ${ }^{38}$ Recent years have seen a renewed interest in teaching vocabulary among educators at all levels, largely because of worrisome literacy among sixth to twelfth graders, English learners in particular.

As many studies attest, vocabulary is the first important step toward and, indeed, the foundation of, school success for English learners and other students. Teaching and Learning Vocabulary: Bringing Research to Practice, a compendium put together by experts from diverse fields, forms the basis of the vocabulary instruction that has helped many English learners and struggling students accelerate their English learning and academic success. ${ }^{39}$

Researchers have found that young children in poverty hear, on average, about 615 words an hour; middle-class children, about 1,251; and children of professionals, about 2,153. ${ }^{40}$ The average six-year-old has a vocabulary of approximately 8,000 words. ${ }^{41} \mathrm{~A}$ child's vocabulary in kindergarten and first grade is a significant predictor of his reading comprehension in the middle and secondary grades; ${ }^{42}$ it also predicts future reading difficulties. ${ }^{43}$

Vocabulary instruction contributes to overall effective instruction by developing students' phonological awareness ${ }^{44}$ and reading comprehension. ${ }^{45}$ For English learners, vocabulary instruction must not only be long term and comprehensive, ${ }^{46}$ but also be taught explicitly in all subject areas before, during, and after reading. ${ }^{47}$ Students benefit the most when teachers provide rich and varied language experiences; teach individual words, noun phrases, and idioms; teach word-learning strategies, such as looking for prefixes and root words; and foster word consciousness that makes clear the importance of learning as many words as possible throughout the day. ${ }^{48}$

Explicit vocabulary instruction entails frequent exposure to a word in multiple forms; ensuring understanding of meaning(s); providing examples of its use in phrases, idioms, and usual contexts; ensuring proper pronun-

\section{In programs where English is the primary language of instruction for literacy development, it is critical for teachers to show respect for the student's primary language and home culture.}

ciation, spelling, and word parts; and, when possible, teaching its cognates, or a false cognate, in the child's primary language.

Reading instruction is quite complex, and all the more so because students use multiple cognitive processes in reading. Over the years, the focus of reading instruction has varied, shifting from decoding, to fluency, and, recently, to comprehension and word meaning. But reading entails more than decoding or fluency or comprehension. It makes use of multiple skills: oral language proficiency, 
phonological processing, working memory, word-level skills (decoding, spelling), and text-level skills, such as scanning, skimming, summarizing, and making inferences. ${ }^{49}$

The National Literacy Panel for LanguageMinority Children and Youth found clear benefits from instruction that covers the key components of reading identified by the National Reading Panel (phonemic awareness, phonics, fluency, vocabulary, and text comprehension).$^{50}$ Other research emphasizes the need for instructional practices to integrate oral language proficiency, reading, and writing. For English learners, for whom oral language proficiency plays an important role in acquiring reading skills, active participation by children during teacher "read-alouds" contributes to vocabulary growth. ${ }^{51}$ For example, open-ended questions and multiple exposure to words during shared reading help children know how to use those words. ${ }^{52}$ Because oral language, reading, and writing draw on common knowledge and cognitive processes, improving students' writing skills should result in improved reading skills. ${ }^{53}$ To help English learners catch up when they fall short in core knowledge, all disciplines must practice vocabulary knowledge, reading, and writing instruction. ${ }^{54}$

To become good readers - to be able to recognize words and comprehend a text simultaneously_English learners require practice at both decoding and fluency. ${ }^{55}$ Teachers must thus give equal attention to decoding, or word recognition, and comprehension. Once English learners can recognize words automatically (automaticity), the focus can shift to overall meaning. For mainstream students, word recognition simply means being able to read a word aloud. For English learners, it also means being able to recognize the word's meaning. Comprehension calls for knowing 85 to 90 percent of the words in a sentence, a question, a paragraph, or any text. ${ }^{56}$ For English learners, therefore, instruction time and attention must be divided among word meaning, decoding, grammatical structures, background knowledge, and comprehension skills. Because English learners begin school, or arrive in the later grades, with a wide variety of educational and literacy backgrounds, schools must assess all language and literacy domains and identify areas where a student might need an additional intervention such as tutoring. Despite these unique demands in instructing secondlanguage writers, however, research on how to teach writing to English learners is scarce. Because no single approach to writing instruction will meet the needs of all students, much more research is needed on interventions that work. ${ }^{57}$

Studies also shed light on the strategic use of the primary language during instruction. For example, in programs where English is the primary language of instruction for literacy development, it is critical for teachers to show respect for the student's primary language and home culture. Just as language and identity are interwoven, so are culture and identity. Strategies that send the message that this student's primary language and culture are valuable might include encouraging the student to use his native language with language peers during activities to build comprehension but to use the new words in English once the task is understood; pairing a new student with a same-language buddy who is familiar with the classroom and school; and using a variety of cooperative learning strategies to create a safe context to practice the new language with peers. 


\section{Integrating Language, Literacy, and Content for Adolescent Readers}

Recent research has identified instructional strategies that seem to be effective with struggling adolescent readers. ${ }^{58}$ National panels and committees concur that these instructional approaches enhance language, reading, and writing skills. ${ }^{59}$ They recommend that math, science, and social studies teachers provide explicit vocabulary instruction for each content area; provide direct and explicit comprehension strategy instruction; use text-based cooperative learning to allow for extended discussion of text meaning and interpretations and for application of new vocabulary; ensure that each subject area involves intensive writing and use of new vocabulary; use technology to support instruction and learning; and conduct ongoing formative assessment of the students.

English learners in middle and high school present schools with a particular problem. Not only are these students expected to master complex course content, often with minimal background knowledge or preparation, but also they have fewer years to master the English language. Because the number of English learners is large and growing, all teachers must understand the factors that affect their language, reading, and content development and be prepared to address them. As of 2000, however, although 41 percent of teachers had taught English learners, only 13 percent had received any specialized training. ${ }^{60}$

According to the Carnegie Council on Advancing Adolescent Literacy, literacy instruction should focus on attacking multisyllabic and technical terms; assessing and providing repeated reading practice if necessary; expanding the emphasis on academic and technical vocabulary, polysemy (multiple-meaning words), etymology, and morphological analysis. Content-area reading should involve explicit instruction in discourse structures, word use, and grammar needed for math, science, social studies, and language arts.

Beyond classroom instruction, the Carnegie panel recommends conducting literacy assessments to assign struggling students to appropriate interventions and to monitor progress. Assessments would cover the primary language as well as English to identify appropriate instruction for recent arrivals. Based on the assessments, the school administration and teams of teachers would meet to respond to variability among English learners.

The panel sets forth an integrated curriculum for English language learners that includes a detailed developmental sequence for learning the English language within all subject areas, as well as traditional social English. In many states, however, the standards that guide the school or district curriculum for English learners differ little from those designed for native English speakers, and give little careful attention to secondlanguage development. English learners need their own ladders of progressions. Unless concrete supports, direction, and examples are attached to the newly approved Common Core State Standards, these standards and the new generation of assessments and new materials to be published alongside them will likely double or triple the longterm English learner population. ${ }^{61}$

A more complex instructional challenge for middle and high schools is the curriculum and structural adjustments necessary to help adolescent newcomers with interrupted formal education or barely any education. New York City schools have 
implemented one program, Reading Instructional Goals for Older Readers (RIGOR), that offers promise here by providing newcomers more time for learning through before- and after-school sessions, Saturday academies, and summer school sessions. ${ }^{62}$ The program consists of intensive English-language instruction through science and social studies instruction. For students with low literacy skills in their own language, RIGOR is offered in both Spanish and English during the day. The extended day schedules, with native language support, help accelerate language, literacy, and knowledge of science and social studies simultaneously. Refugees and students with interrupted formal education accelerated their learning more efficiently in the extended day programs than they did in unstructured English as a Second

\section{Parent support for children's success in school is always important, but it is especially so for the children of immigrants.}

Language classes, remedial courses, or basal readers. Therefore, the central district office now offers grants to allow schools to implement these programs. For district offices to provide additional resources to schools demonstrates how much they value addressing the most needy of secondary school English learners.

Unlike students with interrupted formal education, highly schooled newcomers have substantial background knowledge and mainly need intensive accelerated English programs.
They need a different curriculum design to help them move quickly into general education classes.

\section{Cooperative Learning}

In cooperative learning, teachers plan for students to work in small groups to help one another learn. Cooperative learning offers a wide variety of approaches, but the most effective are those in which students work in mixed-ability groups of four, have regular opportunities to teach each other after the teacher has introduced a lesson, and are recognized based on the learning of all members of the group. ${ }^{63}$

Cooperative learning has been found effective for elementary and secondary students across a broad range of subjects, and it is especially so for English learners who are learning to operate in English. The cooperative activities give them regular opportunities to discuss the content and to use the language of the school in a safe context. Many English learners are shy or reluctant to speak up in class for fear of being laughed at, but in a small cooperative group they can speak and learn from their friends and classmates.

Research has clearly shown the effectiveness of structured cooperative methods for English learners. Margarita Calderón, Rachel Hertz-Lazarowitz, and Robert Slavin ${ }^{64}$ evaluated a program in El Paso, Texas, called Bilingual Cooperative Integrated Reading and Composition, or BCIRC, among English learners who were transitioning from Spanish to English instruction in grades two through four. Compared with a control group of similar English learners, those in BCIRC had significantly higher scores on both English and Spanish reading measures. A second El Paso study, by Calderón and others, ${ }^{65}$ evaluated a similar bilingual program among third 
graders that emphasized cooperative learning and systematic phonics. Once again, students in the cooperative learning classes scored higher than controls on English as well as Spanish reading measures.

Other studies of programs using cooperative learning that have documented positive effects include Spanish-to-English transition approaches evaluated by Maria Carlo, Diane August, and Catherine Snow and by Bill Saunders and Claude Goldenberg. ${ }^{66}$ A first-grade pair learning method called PALS (Peer Assisted Learning Strategies) helps Hispanic students to improve their reading performance ${ }^{67} \mathrm{~A}$ great deal of research has shown that SFA and Expediting Comprehension for English Language Learners (ExC-ELL), both of which have a strong focus on cooperative learning, improve student achievement. ${ }^{68}$

\section{Professional Development}

According to reviews of professional development studies, teachers who work with English learners found professional development most helpful when it provided opportunities for hands-on practice with teaching techniques readily applicable in their classrooms, in-class demonstrations with their own or a colleague's students, and personalized coaching. ${ }^{69}$

Rafael Lara-Alecio and his colleagues ${ }^{70}$ found that ongoing biweekly professional development improved kindergarten teachers' work with English learners. The teachers became more effective in the classroom after receiving training in eight specific strategies: enhanced instruction via planning, student engagement, vocabulary building and fluency, oral language development, literacy development, reading comprehension, parental support and involvement, and reflective practice through portfolio development. Fuhui Tong and her colleagues ${ }^{71}$ attributed the acceleration of English learners' oral language development to well-planned professional development (at least six hours a month for teachers, and three hours a month for paraprofessionals).

The SFA professional development model begins with two days of workshops that group teachers by grade levels so that trainers can address instructional approaches specific to their grade levels. Trainers then provide each teacher three or more follow-up coaching days. Coaches and administrators participate along with teachers and also receive their own sessions on how to make sure that the implementation of all this training is of high quality.

The ExC-ELL professional development begins with five days of workshops on how to teach vocabulary, reading, writing, and subject matter, followed by extensive coaching by the ExC-ELL trainers. The school's principals and the literacy coaches who work with the teachers shadow the trainers initially to practice conducting classroom observations and giving technical feedback to help teachers reflect and set goals. The observations by trainers, coaches, principals, other teachers, and central district administrators also help to validate data on teacher and student performance. Observers collect the data with the ExC-ELL observation protocol using a digital pen and paper that can be docked on a computer to generate reports on the students' use of vocabulary, reading, and writing skills; the effectiveness of cooperative learning; and classroom management. The protocol can generate reports for individual classrooms, for subject area clusters or learning communities, after each observation, or as benchmark assessments or end-of-year reports. 
Researchers, school administrators, and policy makers have neglected for too long the relationship between professional development and student learning. Designing, measuring, and providing effective professional development is often a complex undertaking for schools and school districts. Yet, without knowing how and how well professional development is implemented in each classroom, they cannot determine its impact on student learning. ${ }^{72}$ Schools need to establish clear causal links between their particular teachers' needs, their teacher professional development offerings, and their student outcomes. Measures of student outcomes on standardized achievement scores alone will not give a clear picture of the complex ways in which professional development is linked with teacher effectiveness and student learning. Direct observation of teacher knowledge and skills, as well as the delivery of those skills in the classroom, makes those links clearer. Several recent studies have examined how observational protocols that measure various domains of teaching have affected student outcomes. ${ }^{73}$ These observational protocols offer a vehicle for exploring the transfer of skills and knowledge from teacher preparation offerings into their active teaching repertoire, as well as how their teaching affects students, in order to evaluate teachers' effectiveness. ${ }^{74}$

\section{Parent and Family Support}

Parent support for children's success in school is always important, ${ }^{75}$ but it is especially so for the children of immigrants. English learners are likely to have to balance cultural, linguistic, and social differences between home and school, so open communication and positive relationships across the home-school divide are crucial. ${ }^{76}$ Schools serving many English learners need to focus on aspects of children's development beyond those directly affected by classroom teaching. SFA schools, for example, establish "Solutions Teams" to organize resources and energies to deal with these issues. ${ }^{77}$

Parents need to feel that they play a meaningful role in school decisions that affect them and their children. Schools may, for example, establish a Building Advisory Team to review schoolwide discipline policies, suggest opportunities for parent and community involvement, review homework guidelines, and suggest ways to improve school climate. The team should ensure openness to participation by parents who do not speak English.

Schools should also create many opportunities for parents and other community members to volunteer in the school. Volunteer opportunities may include tutoring, homework help, or other academic assistance, as well as helping with sports, cultural programs, food service, and fundraising. Parents should feel that they are welcome at school and that their issues are important. Many SFA schools offer parents a "Second Cup of Coffee" to give them a chance to sit with a parent aide or other staff member to discuss ways to help their children at home, as well as parenting issues such as behavior management and finances. These programs should be offered in the parents' home language if at all possible. Other communications may be informal. School staffs may be encouraged to look for opportunities to speak with parents as they drop their children off in the morning, for example, or to share good news about individual children. Good news phone calls, texts, or e-mail can make a big difference in how parents feel about the school.

Children need to be in school on time every day. Effective programs for attendance collect information early in the day and act on it immediately, so that lateness and missing 
days of school never come to be seen as normal. Providing awards for children who improve their attendance can also help build supportive relationships between home and school. Despite every effort at preventing absences and tardiness, problems will arise with individual children. School staffs should formulate generic intervention plans for predictable types of problems, such as truancy, and then modify them for individual circumstances if necessary.

In essence, SFA schools try to negotiate opportunities to provide health, mental health, and social services at the school or in close coordination with the school. For example, school staff should know how to help families with issues such as health problems, counseling, immigration problems, food, shelter, and adult literacy. Ideally these services can be provided at the school site, but if not, school staffs should still help make sure that families have easy access to services that affect children.

\section{Tutoring and Other Interventions for} Struggling Readers

When children are struggling in reading, the most effective intervention is one-to-one tutoring by well-trained, certified teachers, ${ }^{78}$ and the most effective tutors use structured phonetic programs. ${ }^{79}$ Evaluations of the most widely used phonetic program, Reading Recovery, show that it is successful with English learners, ${ }^{80}$ but other phonetic programs have had more positive effects on the reading of struggling students. Reading Rescue, for example, was found successful with Spanish-dominant urban first graders. Two other such programs are Early Steps and Targeted Reading Instruction. ${ }^{81}$

Well-trained, well-supervised paraprofessionals using structured, phonetic models can also be effective tutors, as shown by programs called Sound Partners and Howard Street Tutoring. ${ }^{82}$ Well-structured volunteer programs, such as Book Buddies ${ }^{83}$ can be effective as well. Several effective tutoring programs—-such as Corrective Reading; Read, Write, and Type; and SHIP — use structured, phonetic methods with small groups of two to six students. ${ }^{84}$

Researchers have also provided strong evidence that effective whole-class programs can prevent struggling readers from falling behind. Proven forms of cooperative learning, such as Cooperative Integrated Reading and Composition and its bilingual version (BCIRC), and PALS, discussed earlier, are particularly effective for students in the bottom quarter of their classes. ${ }^{85}$ Cooperative learning can be as effective as one-to-one tutoring, but it should be seen as a way to reduce the numbers of children who will need tutoring, not as a substitute.

\section{Monitoring Implementation and Outcomes}

Educators seeking to improve instruction for English learners must pay close attention not only to the student outcomes a program achieves but also to how well each element of the program is implemented. In many comprehensive reform models, an on-site facilitator or coach helps implement the program and keep track of intermediate outcomes. In SFA, for example, a full-time facilitator helps all staff implement all aspects of the program, observes teachers and gives them feedback, and enables teachers of the same program component to share ideas and answer each others' questions. Facilitators work with the school staff to use online data tools to monitor continuously the reading progress of all students and to help use the data to identify students who may need tutoring, may have 
problems at home, or may need to accelerate to higher-level instruction. No program is self-implementing; a model is only as good as the care with which it is implemented. Maintaining high-quality, adaptive, and effective innovations takes constant attention and

\section{Cooperative learning can} be as effective as one-to-one tutoring, but it should be seen as a way to reduce the numbers of children who will need tutoring, not as a substitute.

effort. Technology-based observation protocols and performance assessment tools help teachers, the professionals who coach them, and the administrators who oversee them continually gauge the learning progressions of teachers and students.

The Council on Advancing Adolescent Literacy $^{86}$ also offers a comprehensive approach for re-engineering America's middle and high schools to prepare all students, including English learners, for college and careers. The approach has seven components. First, the school culture is organized for learning. Quality instruction is the central task that organizes everyone's work. Teachers feel personal responsibility, and the principals support their efforts. Second, student achievement data drives decisions about instruction, scheduling, and interventions. Staff receive supports to gather and analyze real-time data from formative assessments to inform instruction and to target remediation.
Third, time, energy, and materials are focused on areas deemed critical for raising student achievement. Fourth, instructional leadership is strong. Principals work in partnership with subject area specialists, literacy coaches, and other professional development experts to ensure implementation of critical programs. Fifth, all content teachers participate willingly in professional development because they recognize the need to improve their work and the importance of literacy skills to content-area learning. Sixth, targeted interventions are used for struggling readers and writers. Multitiered instruction helps students build the skills and strategies needed for successes. A logical progression of interventions is available, to which learners are assigned based on their needs. Finally, all content-area classes are permeated by a strong literacy focus. Teachers offer reading and writing instruction in all core classes (math, science, language arts, social studies).

To complement high-quality instruction by ESL teachers and all content teachers, schoolwide teams supported by knowledgeable administrators meet regularly to align curriculum, plan cross-content projects, address student concerns, and monitor English learner progress. Finally, counselors who understand and are able to respond to the challenges facing English learners are available to students. ${ }^{87}$

An Elementary School Case. Project English Language and Literacy Acquisition (ELLA), a five-year randomized trial study funded by the Institute of Education Sciences, restructured a transitional bilingual education program in which students were moving toward instruction in English alone. ${ }^{88}$ The experimental component of the program resembled a dual-language, or developmental, program, in which two languages are developed all 
through K-12. The two languages, Spanish and English, were separated in instruction, expectations were high during instruction in both languages, and the interventions included targeted and deliberate higherorder questions.

Within that structure, the home-school connection was clear. Family activities were aligned with the school curriculum and were sent home in two languages. The teachers and paraprofessionals received monthly professional development and created a professional portfolio to enable them to reflect on their practice and improve their teaching skills. ${ }^{89}$

The leadership in the district directed and supported the restructuring. It used the program evaluation to compare the enhanced bilingual program model with the district's other bilingual programs by using classroom observations of the teachers in both with a specified observation tool. ${ }^{90}$

\section{A Middle and High School Case. ExC-ELL} was a five-year effort funded by the Carnegie Corporation of New York to design and test a professional development model for core content teachers who have English learners in their classrooms. The aim was to integrate the teaching of vocabulary, reading comprehension, and writing skills into all math, science, social science, and language arts classes. The foundation of instruction was cooperative learning for language and literacy development, performance assessments, and the use of an online observation protocol to capture teacher and student learning progressions.

The professional development consisted of three phases. An initial fifty-hour training session was followed by yearlong coaching by experts, administrators, and peers, and then by the creation of learning communities. In that third phase all content, ESL, and sheltered instruction teachers (those who specialize in teaching core content to English learners), as well as their coaches and administrators, worked together to reengineer the way they addressed the diversity of English learners, struggling readers, and general education students. The instructional focus described above for literacy and the eight basic principles for creating an effective context for teaching reading to adolescents were the targets of the study and school restructuring. After two years, the reading scores of English learners improved 45 percent, meaning that the majority of long-term English learners, students with interrupted formal education, special education students, and newcomers attained or exceeded grade level in reading. In turn, the experimental schools advanced from low-performing to high-performing in two years. ${ }^{91}$

\section{Concluding Remarks}

Experts on teacher education, languageminority children, and general reading and writing instruction agree that effective teaching is critical to student learning. Concomitantly, other research shows that certain school structures facilitate effective teaching. ${ }^{92}$ In short, effective instruction is nested in effective school structures.

As larger numbers of English learners and struggling readers reach America's middle and high schools, more and more of the nation's teachers are discovering that they need to learn how to teach these students effectively. Elementary teachers recognize that they must provide more challenging and meaningful instruction to prepare their students for secondary schools. Mainstream content teachers in middle and high schools, having seen the many English learners spilling out of ESL or 
sheltered classrooms and into theirs, want to do what is right for all students. What these teachers need today from the nation's schools are the structures and support that will enable them to move in these directions. Without better support for teachers, we cannot expect better student outcomes.

As states begin debating adoption of core standards, we can be certain that accountability to all students, including English learners, will increase. These standards will surely affect the curriculum, the way students are assessed, and how teacher and administrator accountability is measured and documented. Language development progressions, reading comprehension, and writing targets will be developed along with the accountability measures for the core subjects. English learners will no longer be assessed only for oral language; they will be tested for each discipline.

Although reforms and interventions are needed in every grade, there are compelling reasons to begin in the early grades. It is easier to build a strong foundation with quality programs in preschool to the third grade, when children's needs are much more manageable and teachers are imparting new skills rather than remediating gaps. Teachers' knowledge about how children acquire languages, their grasp of when and how to maximize the use of the primary language spoken in the home, and their modeling of academic discourse in the first and second languages can have important effects on how children learn language and content. ${ }^{93}$

The comprehensive studies that we have reviewed show that successful schools work simultaneously on student formative assessments, school structures, professional development, teacher support, and effective instruction for English learners. The implications for school districts, state departments of education, and the U.S. Department of Education are that forthcoming regulations need to focus on whole-school interventions for English learners. Schools need time to stop and to retool all educators through comprehensive professional developmentan ambitious undertaking that will require appropriate funding. 


\section{Endnotes}

1. Alba Ortiz and Alfredo J. Artiles, "Meeting the Needs of ELLs with Disabilities: A Linguistically and Culturally Responsive Model," in Best Practices in ELL Instruction, edited by Guofang Li and Patricia A. Edwards (New York: Guilford Press, 2010), pp. 247-72.

2. J. Stanley Pottinger, "Identification of Discrimination and Denial of Services on the Basis of National Origin," official communication between the Department of Health, Education, and Welfare, Office of the Secretary, and U.S. school districts with more than 5 percent national-origin minority group children regarding the identification of discrimination and denial of services on the basis of national origin (Washington, D.C., May 25, 1970) (www2.ed.gov/about/offices/list/ocr/ellresources.html).

3. Section 9101 of Title IX Elementary and Secondary federal statute defines a Limited English Proficient individual as one who is between the ages of three and twenty-one, is enrolled or is preparing to enroll in an elementary or secondary school, was not born in the United States or whose native language is not English, and who may face diminished opportunities within society because of difficulties in speaking, reading, writing, or understanding the English language; subsections have been excluded. For a full definition, see www2.ed.gov/policy/elsec/leg/esea02/pg107.html.

4. Eugene E. García, Bryant T. Jensen, and Kent Scribner, “The Demographic Imperative," Educational Leadership April (2009): 8-13.

5. English learners (ELs) are also referred to as English as a Second Language (ESL) students, English Language Learners (ELLs), and Language Minority Children, although this last label refers to children who may already be proficient English speakers but whose parents, on the Home Language Survey, indicated the use of a language other than English in their home. Additional labels include Limited English Proficient (LEP), a federal designation for children who are learning English.

6. Jeanne Batalova, Michael Fix, and Julie Murray, English Language Learner Adolescents: Demographics and Literacy Achievements: Report to the Center for Applied Linguistics (Washington: Migration Policy Institute, 2005); Jeanne Batalova, Michael Fix, and Julie Murray, Measures of Change: The Demography and Literacy of Adolescent English Learners-A Report to Carnegie Corporation of New York (Washington: Migration Policy Institute, 2007) (www.migrationpolicy.org/pubs/Measures_of_Change.pdf).

7. Jeanne Batalova and Margie McHugh, Number and Growth of Students in U.S. Schools in Need of English Instruction (Washington: Migration Policy Institute, 2010) (www.migrationinformation.org/integration/ ellcenter.cfm).

8. Ibid.

9. Patricia Gándara and Megan Hopkins, "The Changing Linguistic Landscape of the United States,” in Forbidden Language: English Learners and Restrictive Language Policies, edited by Patricia Gándara and Megan Hopkins (Teachers College Press, 2010), pp. 7-19.

10. George J. Borjas, "Poverty and Program Participation among Immigrant Children," in this volume; Gándara and Hopkins, "The Changing Linguistic Landscape of the United States" (see note 9).

11. Georgina Earnest Garcia, Gail McKoon, and Diane August, "Language and Literacy Assessment of Language-Minority Students," in Developing Literacy in Second-Language Learners: Report of the 
National Literacy Panel on Language-Minority Children and Youth, edited by Diane August and Timothy Shanahan (Mahwah, N.J.: Lawrence Erlbaum Associates, 2006), pp. 597-625.

12. Laurie Olsen, Reparable Harm: Fulfilling the Unkept Promise of Educational Opportunity for Long-Term English Learners (Long Beach, Calif.: Californians Together, 2010) (www.californianstogether.org).

13. Richard Ingersoll, Core Problems: Out-of-Field Teaching Persists in Key Academic Courses and HighPoverty Schools (Washington: Education Trust, 2008) (www.edtrust.org/de/publication/core-problems).

14. Ortiz and Artiles, "Meeting the Needs of ELLs with Disabilities" (see note 1).

15. Pew Hispanic Center, "Fact Sheet on Hispanic School Achievement: Catching Up Requires Running Faster than White Youth" (Washington: Pew Hispanic Center, 2004) (www.pewtrusts.org/news_room_ detail.aspx?id=16064).

16. See Charles T. Clotfelter, Helen F. Ladd, and Jacob L. Vigdor, "The Academic Achievement Gap in Grades 3 to 8," Review of Economics and Statistics 91 (2009): 398-419. The authors' findings suggest the need for research designs that disaggregate data by cohorts. In their study on the achievement gap in grades three through eight, they report steady academic progress among Hispanic students. The authors hypothesize that their findings may contradict most other similar studies, because their investigation followed the same students over time, whereas other studies factor in testing scores for new Latino immigrants who may be pulling down overall scores. They write, "Thus an achievement gap based on repeated cross sections would be larger than those we calculate based on intact cohorts and would grow rather than shrink with each grade" (p. 403). Furthermore, in their press release about the study, they note, "When we adjust for the lower parental education and higher poverty rates of Hispanic students, they actually outperform their Anglo counterparts by the time they reach sixth grade" (p. 403).

17. Robert Slavin and others, "Reading and Language Outcomes of a Five-Year Randomized Evaluation of Transitional Bilingual Education,” Best Evidence Encyclopedia (BEE) (2010) (www.bestevidence.org/word/ bilingual_education_Apr_22_2010.pdf). Manuscript submitted for publication.

18. Kenji Hakuta, Yuko Goto Butler, and Daria Witt, How Long Does It Take English Learners to Attain Proficiency? (University of California Linguistic Minority Research Institute Policy Report 2000-1, 2000). (www.eric.ed.gov/ERICWebPortal/search/detailmini.jsp?_nfpb=true\&_\&ERICExtSearch_SearchValue_0= ED443275\&ERICExtSearch_SearchType_0=no\&accno=ED443275).

19. Robert E. Slavin, "What Works? Issues in Synthesizing Educational Program Evaluations," Educational Researcher 37 (2008): 5-14.

20. Robert E. Slavin and Margarita Calderón, eds., Effective Programs for Latino Students (Mahwah, N.J.: Lawrence Erlbaum Associates, Inc., 2001); Alan Cheung and Robert E. Slavin, "Effective Reading Programs for English Language Learners and Other Language Minority Students," Bilingual Research Journal 29 (2005): 241-67; Diane August and Timothy Shanahan, eds., Developing Literacy in SecondLanguage Learners: Report of the National Literacy Panel on Language-Minority Children and Youth (Mahwah, N.J.: Lawrence Erlbaum Associates, 2006); Diane August and others, "Developing Literacy in English-language Learners: An Examination of the Impact of English-Only versus Bilingual Instruction," in Childhood Bilingualism: Research on Infancy and Child Development, edited by Peggy McCardle and Erika Hoff (Clevedon, England: Multilingual Matters, 2005), pp. 91-107; Diane August and others, 
"Development of Literacy in Spanish-speaking English-language Learners: Findings from a Longitudinal Study of Elementary School Children," International Dyslexia Association 31 (2005): 17-19.

21. Ortiz and Artiles, "Meeting the Needs of ELLs with Disabilities" (see note 1).

22. Comprehensive School Reform Quality Center, Report on Elementary School Comprehensive School Reform Models (Washington: American Institutes for Research, 2006), and Comprehensive School Reform Quality Center, Report on Middle and High School Comprehensive School Reform Models (Washington: American Institutes for Research, 2006).

23. Robert E. Slavin and others, eds., Two Million Children: Success for All (Thousand Oaks, Calif.: Corwin, 2009).

24. Catherine E. Snow, M. Susan Burns, and Peg Griffin, eds., Preventing Reading Difficulties in Young Children: Committee on the Prevention of Reading Difficulties in Young Children (Washington: National Research Council, 1998), pp. 230-32.

25. Bette Chambers and others, "Achievement Effects of Embedded Multimedia in a Success for All Reading Program," Journal of Educational Psychology 98 (2006): 232-55; Bette Chambers and others, "Technology Infusion in Success for All: Reading Outcomes for First Graders," Elementary School Journal 109 (2008): $1-15$.

26. August and others, "Development of Literacy in Spanish-Speaking English-Language Learners" (see note 20).

27. Meg Livingston Asensio and John Flaherty, Effects of Success for All on Reading Achievement in California Schools (Los Alamitos, Calif.: WestEd, 1997).

28. John Nunnery and others, "An Assessment of Success for All Program Component Configuration Effects on the Reading Achievement of At-Risk First Grade Students" (paper presented at the annual meeting of the American Educational Research Association, Chicago, April 1996).

29. See National Research Council, Robert E. Slavin, and Nancy A. Madden, "Effects of Success for All on the Achievement of English Language Learners" (paper presented at the annual meeting of the American Educational Research Association, New Orleans, 1994).

30. Steven M. Ross, Lana J. Smith, and John Nunnery, The Relationship of Program Implementation Quality and Student Achievement (paper presented at the annual meeting of the American Educational Research Association, San Diego, April, 1998).

31. Bette Chambers and others, Effects of Success for All with Embedded Video on the Beginning Reading Achievement of Hispanic Children: Technical Report (Center for Research and Reform in Education, Johns Hopkins University, 2005).

32. Geoffrey D. Borman and others, "Final Reading Outcomes of the National Randomized Field Trial of Success for All," American Educational Research Journal 44 (2007): 701-31.

33. For the full report see www.nwp.org/cs/public/print/resource/3019.

34. Philip A. Streifer, Using Data to Make Better Educational Decisions (Lanham, Md.: Scarecrow Press, 2002). 
35. Jerome Freiberg, T. A. Stein, and Shwu-yong Huong, "Effects of a Classroom Management Intervention on Student Achievement in Inner-City Elementary Schools," Educational Research and Evaluation 1 (1995): 36-66.

36. Carolyn M. Evertson, Edmund T. Emmer, and Murry Worsham, Classroom Management for Elementary Teachers, 8th ed. (Boston: Allyn \& Bacon, 2009).

37. Sam Stringfield, "Organizational Learning and Current Reform Efforts," in Schools as Learning Communities, edited by Kenneth A. Leithwood and Karen Seashore Louis (Lisse, Netherlands: Swets \& Zeitlinger, 1998), pp. 255-68.

38. Michael F. Graves, The Vocabulary Book: Learning and Instruction (Teachers College Press, 2006).

39. Margarita Calderón and others, "Bringing Words to Life in Classrooms with English Language Learners," in Teaching and Learning Vocabulary: Bringing Research to Practice, edited by Elfriede Hiebert and Michael L. Kamil (Mahwah, N.J.: Lawrence Erlbaum, 2005), pp. 115-36.

40. Betty Hart and Todd Risely, “The Early Catastrophe: The 30 Million Word Gap,” American Educator 27 (Spring 2003): 4-9.

41. Monique Senechal and Edward H. Cornell, "Vocabulary Acquisition through Shared Reading Experiences," Reading Research Quarterly 28, no. 4 (1993): 361-74.

42. Anne E. Cunningham, "Vocabulary Growth through Independent Reading and Reading Aloud to Children," in Teaching and Learning Vocabulary, edited by Hiebert and Kamil, pp. 45-68; Anne E. Cunningham and Keith E. Stanovich, "Early Reading Acquisition and Its Relation to Reading Experience and Ability 10 Years Later," Developmental Psychology 33, no. 6 (1997): 934-45.

43. Jeanne S. Chall, Vicki A. Jacobs, and Luke E. Baldwin, The Reading Crisis: Why Poor Children Fall Behind (Harvard University Press, 1990).

44. William E. Nagy, "Why Vocabulary Instruction Needs to Be Long-Term and Comprehensive," in Teaching and Learning Vocabulary, edited by Hiebert and Kamil, pp. 27-44.

45. Isabel L. Beck, Charles A. Perfetti, and Margaret G. McKeown, "The Effects of Long-Term Vocabulary Instruction on Lexical Access and Reading Comprehension,” Journal of Educational Psychology 74 (1982): $506-21$.

46. Maria Carlo, Diane August, and Catherine E. Snow, "Sustained Vocabulary-Learning Strategy Instruction for English Language Learners," in Teaching and Learning Vocabulary, edited by Hiebert and Kamil, pp. $137-54$.

47. Calderón and others, "Bringing Words to Life in Classrooms with English Language Learners" (see note 39); Margarita Calderón and Liliana Minaya-Rowe, Designing and Implementing Two-Way Bilingual Programs: A Step-by-Step Guide for Administrators, Teachers, and Parents (Thousand Oaks, Calif.: Corwin Press, 2003).

48. Graves, The Vocabulary Book (see note 38).

49. Diane August and Timothy Shanahan, eds., Developing Reading and Writing in Second-Language Learners: Lessons from the Report of the National Literacy Panel on Language-Minority Children and Youth (New York: Routledge, 2008). 
50. August and Shanahan, eds., Developing Literacy in Second-Language Learners (see note 20); August and Shanahan, eds., Developing Reading and Writing in Second-Language Learners (see note 49).

51. August and Shanahan, eds., Developing Reading and Writing in Second-Language Learners (see note 49).

52. Claudia Robbins and Linnea Ehri, "Reading Storybooks to Kindergartners Helps Them Learn New Vocabulary Words," Journal of Educational Psychology 86, no. 1 (1994): 54-64; Cunningham, "Vocabulary Growth through Independent Reading and Reading Aloud to Children” (see note 42).

53. Steve Graham and Michael Hebert, Writing to Read: Evidence for How Writing Can Improve Reading. A Carnegie Corporation Time to Act Report (Washington: Alliance for Excellent Education, 2010) (www.all4ed.org/files/WritingToRead.pdf).

54. Margarita Calderón, "Professional Development for Teachers of English Language Learners and Striving Readers," in Handbook of Literacy and Research on Literacy Instruction: Issues of Diversity, Policy, and Equity, edited by Leslie Mandel-Morrow, Robert Rueda, and Diane Lapp (New York: Guilford Press, forthcoming).

55. William Grabe, Reading in a Second Language: Moving from Theory to Practice (Cambridge University Press, 2009); William E. Nagy, Teaching Vocabulary to Improve Reading Comprehension (Newark, Del.: International Reading Association, 1998); S. Jay Samuels, "The Method of Repeated Readings," Reading Teacher 32, no. 4 (1979): 403-08.

56. Steven A. Stahl and Marilyn M. Fairbanks, "The Effect of Vocabulary Instruction: A Model-Based MetaAnalysis," Review of Educational Research 56, no. 1 (1986): 72-110.

57. Steve Graham and Dolores Perin, Writing Next: Effective Strategies to Improve Writing of Adolescents in Middle and High Schools-A Report to Carnegie Corporation of New York (Washington: Alliance for Excellent Education, 2007) (www.all4ed.org/publication_material/reports/writing_next).

58. Michael L. Kamil, Adolescents and Literacy: Reading for the 21st Century (Washington: Alliance for Excellent Education, 2003); Gina Biancarosa and Catherine Snow, Reading Next: A Vision for Action and Research in Middle and High School Literacy-A Report to Carnegie Corporation of New York (2nd ed.) (Washington: Alliance for Excellent Education, 2006) (www.all4ed.org/files/ReadingNext.pdf); Graham and Perin, Writing Next (see note 57).

59. Deborah J. Short and Shannon Fitzsimmons, Double the Work: Challenges and Solutions to Acquiring Language and Academic Literacy for Adolescent English Language Learners (Washington: Alliance for Excellent Education, 2007) (www.all4ed.org/files/DoubleWork.pdf); Margarita Calderón, Teaching Reading to English Language Learners, Grades 6-12: A Framework for Improving Achievement in the Content Areas (Thousand Oaks, Calif.: Corwin Press, 2007); Margarita E. Calderón and Liliana Minaya-Rowe, Preventing Long-Term ELs (Thousand Oaks, Calif.: Corwin Press, 2010).

60. National Center for Education Statistics, Common Core of Data: Information on Public Schools and School Districts in the United States (Washington: National Center for Education Statistics, 2002) (retrieved from http://nces.ed.gov/ccd); Gándara and Hopkins, "The Changing Linguistic Landscape of the United States" (see note 9).

61. Olsen, Reparable Harm (see note 12). 
62. Margarita E. Calderón, RIGOR! Reading Instructional Goals for Older Readers: Reading Program for 6th-12th Students with Interrupted Formal Education (New York: Benchmark Education Co., 2007).

63. Slavin and Madden, "Effects of Success for All on the Achievement of English Language Learners" (see note 29); Slavin and others, "Reading and Language Outcomes of a Five-Year Randomized Evaluation of Transitional Bilingual Education" (see note 17); Cheung and Slavin, "Effective Reading Programs for English Language Learners and Other Language Minority Students” (see note 20); Margarita E. Calderón, Rachel Hertz-Lazarowitz, and Robert E. Slavin, "Effects of Bilingual Cooperative Integrated Reading and Composition on Students Making the Transition from Spanish to English Reading," Elementary School Journal 99 (1998): 153-65; Stuart Webb, "Receptive and Productive Vocabulary Sizes of L2 Learners," Studies in Second Language Acquisition 30 (2008): 79-95.

64. Calderón, Hertz-Lazarowitz, and Slavin, "Effects of Bilingual Cooperative Integrated Reading and Composition on Students Making the Transition from Spanish to English Reading” (see note 63).

65. Calderón and others, "Bringing Words to Life in Classrooms with English Language Learners" (see note 39).

66. Carlo, August, and Snow, "Sustained Vocabulary-Learning Strategy Instruction for English Language Learners" (see note 46); Bill Saunders and Claude Goldenberg, "Four Primary Teachers Work to Define Constructivism and Teacher-Directed Learning: Implications for Teacher Assessment," Elementary School Journal 97 (1996): 139-61.

67. Mary Beth Calhoon and others, "Improving Reading Skills in Predominantly Hispanic Title 1 First-Grade Classrooms: The Promise of Peer-Assisted Learning Strategies," Learning Disabilities Research \& Practice 21 (2006): 261-72.

68. Slavin and others, eds., Two Million Children (see note 23); Calderón, Teaching Reading to English Language Learners, Grades 6-12 (see note 59). For practical guides and training in cooperative learning, contact: Success for All Foundation at www.successforall.org and Margarita Calderón at www.margarita calderon.org.

69. Margarita Calderón, Preparing Math, Science, and Social Studies Teachers with English Language Learners. Report to The Carnegie Corporation of New York (New York: Carnegie Corporation, 2009); D. Marsh and Margarita Calderón, “Applying Research on Effective Bilingual Instruction in a Multi-District In-service Teacher Training Program," National Association for Bilingual Education Journal 12 (1989): 133-52; M. Calderón, "An Ethnographic Study of Coaching and Its Impact on Training Teachers of Limited English Proficient Students” (Ph.D. diss., Claremont Graduate School/San Diego State University, 1984).

70. Rafael Lara-Alecio and others, “Teachers' Pedagogical Differences among Bilingual and Structured English Immersion Kindergarten Classrooms in a Randomized Trial Study," Bilingual Research Journal 32, no. 1 (2009): 77-100.

71. Fuhui Tong and others, "Accelerating Early Academic Oral English Development in Transitional Bilingual and Structured English Immersion Programs," American Educational Research Journal 45, no. 4 (2008): $1011-44$.

72. Bruce Joyce and Emily Calhoun, Models of Professional Development: A Celebration of Educators (Thousand Oaks, Calif.: Corwin Press, 2010).

73. Andrew J. Mashburn and others, "Measures of Classroom Quality in Pre-Kindergarten and Children's Development of Academic, Language and Social Skills," Child Development 79 (May/June 2008): 732-49; 
Pam Grossman, Karen Hammerness, and Morva McDonald, "Redefining Teacher: Re-imagining Teacher Education,” Teachers and Teaching: Theory and Practice 15 (2009): 273-90; Calderón, Teaching Reading to English Language Learners, Grades 6-12 (see note 59).

74. National Research Council, Committee on the Study of Teacher Preparation Programs in the United States, Preparing Teachers: Building Evidence for Sound Policy (Washington: National Research Council, 2010).

75. See Joyce L. Epstein, "School/Family/Community Partnerships: Caring for the Children We Share," Phi Delta Kappan 76 (1995): 701-12.

76. Claude Goldenberg, Roberto Rueda, and Diane August, "Synthesis: Sociocultural Contexts and Literacy Development," in Developing Literacy in Second-Language Learners: Report of the National Literacy Panel on Language-Minority Children and Youth, edited by Diane August and Timothy Shanahan (Mahwah, N.J.: Erlbaum and Associates, 2006), pp. 249-69.

77. Slavin and others, eds., Two Million Children (see note 23).

78. Robert E. Slavin and others, "Effective Programs for Struggling Readers: A Best-Evidence Synthesis. Educational Research Review" (forthcoming).

79. Ibid.

80. Kathy Escamilla, "Descubriendo la Lectura: An Early Intervention Literacy Program in Spanish," Literacy, Teaching, and Learning 1 (1994): 57-70.

81. Linnea C. Ehri and others, "Reading Rescue: An Effective Tutoring Intervention Model for LanguageMinority Students Who Are Struggling Readers in First Grade," American Educational Research Journal 44 (2007): 414-48; Darrell Morris, Beverly Tyner, and Jan Perney, "Early Steps: Replicating the Effects of a First-Grade Reading Intervention Program," Journal of Educational Psychology 92 (2000): 681-93; Lynn Vernon-Feagans and others, "The Targeted Reading Intervention (TRI): A Classroom Teacher Tier 2 Intervention to Help Struggling Readers in Early Elementary School" (paper presented at the annual meetings of the Society for Research on Effective Education, Crystal City, Va., March, 2009).

82. For Sound Partners, see Patricia F. Vadasy, Elizabeth A. Sanders, and Sarah Tudor, "Effectiveness of Paraeducator-Supplemented Individual Instruction: Beyond Basic Decoding Skills," Journal of Learning Disabilities 40 (2007): 508-25; for Howard Street Tutoring, see Kathleen J. Brown, Darrell Morris, and Matt Fields, "Intervention after Grade 1: Serving Increased Numbers of Struggling Readers Effectively," Journal of Literacy Research 37 (2005): 61-94.

83. Joanne D. Meier and Marcia Invernizzi, "Book Buddies in the Bronx: Testing a Model for America Reads," Journal of Education for Students Placed At Risk 6 (October 2001): 319-33.

84. For Corrective Reading, see Kerry Hempenstall, "Corrective Reading: An Evidence-Based Remedial Reading Intervention,” Australasian Journal of Special Education 32 (2008): 23-54; for Read, Write, and Type, see Joseph K. Torgesen and others, "Computer Assisted Instruction to Prevent Early Reading Difficulties in Students at Risk for Dyslexia: Outcomes from Two Instructional Approaches," Annals of Dyslexia 60 (2009): 40-56; for SHIP, see Barb Gunn and others, "Fostering the Development of Reading Skill through Supplemental Instruction: Results for Hispanic and Non-Hispanic Students," Journal of Special Education 39 (2005): 66-85. 
85. Robert J. Stevens and Robert E. Slavin, "Effects of a Cooperative Learning Approach in Reading and Writing on Handicapped and Nonhandicapped Students' Achievement, Attitudes, and Metacognition in Reading and Writing," Elementary School Journal 95 (1995): 241-62; for BCIRC, see Calderón, HertzLazarowitz, and Slavin, "Effects of Bilingual Cooperative Integrated Reading and Composition on Students Making the Transition from Spanish to English Reading” (see note 63); for PALS, see Patricia G. Mathes and Allison E. Babyak, "The Effects of Peer-Assisted Literacy Strategies for First-Grade Readers with and without Additional Mini-Skills Lessons," Learning Disabilities Research \& Practice 16 (2001): 28-44.

86. For the full report, see www.nwp.org/cs/public/print/resource/3019.

87. Tamara Lucas, Ana María Villegas, and Margaret Freedson-Gonzalez, "Linguistically Responsive Teacher Education: Preparing Classroom Teachers to Teach English Language Learners," Journal of Teacher Education 59 (2008): 361-73.

88. Rafael Lara-Alecio, Beverly J. Irby, and Fuhui Tong, "Project ELLA: The Results of a Five-Year Randomized Trial Study" (symposium at the annual meeting of the American Educational Research Association, Denver, May 2010).

89. Beverly J. Irby and others, "What Administrators Should Know about a Research-Based Oral Language Development Intervention for English Language Learners: A Description of Story Retelling and Higher Order Thinking for English Language Acquisition," International Journal of Educational Leadership Preparation 3 (2009): 1-19.

90. Rafael Lara-Alecio and Richard I. Parker, “A Pedagogical Model for Transitional English Bilingual Classrooms,” Bilingual Research Journal 18 (1994): 119-33.

91. Calderón and Minaya-Rowe, Preventing Long-Term ELs (see note 59).

92. Michael Fullan, Motion Leadership (Thousand Oaks, Calif.: Corwin Press, 2010); Thomas J. Sergiovanni, Rethinking Leadership: A Collection of Articles (Thousand Oaks, Calif.: Corwin Press, 2007).

93. Keira Gebbie Ballantyne, Alicia R. Sanderman, and Nicole McLaughlin, Dual Language Learners in the Early Years: Getting Ready to Succeed in School (Washington: National Clearinghouse for English Language Acquisition, 2008) (www.ncela.gwu.edu/resabout/ecell/earlyyears.pdf). 